\title{
ARRANGEMENT AND TERMINOLOGY OF THE MAIN STRUCTURAL MEMBERS OF THE UNDERSTRUCTURE IN JAPANESE AND BRITISH VERNACULAR HOUSES
}

\author{
Comparative studies in the terminology of traditional timber construction Part 2
}

日本とイギリスの民家における軸部主要部材の配置と用語法

伝統木造用語に関する比較研究 その 2

\author{
Toru HORIE* and Shinya KANEKO** \\ 堀江 亨, 金子晋也
}

\begin{abstract}
This study aims to identify the semantic range and differences in terms for the main structural members of vernacular timber houses in Japan and Britain, focusing on the understructure. Analysis of terms in glossaries and publications identified key characteristics of arrangement and terminology. The terminology of posts (hashira) and plates (keta) varies depending on the nave (joya)-aisle (geya) arrangement. Due to the truss arrangement, British beams are basically set crosswise, whereas Japanese beams are set crosswise and lengthwise and have various names. In Britain, curved timbers are framed symmetrically in a truss, whereas in Japan they are used supplementarily.
\end{abstract}

Keywords : vernacular houses, terminology, nave (joya), aisle (geya), truss, bay 民家, 用語法, ネイブ(上屋), アイル下屋)，トラス, ベイ

\section{Motive and purpose of this study}

Traditional buildings provide evidence of architectural techniques and cultures of previous eras, and significantly affect how architecture is practiced today and the future. Architectural terms describe the most fundamental concepts for understanding both traditional and modern building systems. However, as discussed below, there is no well-established terminology of Japanese traditional architecture (especially architecture rooted in native culture, hereinafter referred to as vernacular architecture); and translation of such terminology into other languages, especially English, has not yet been considered.

To address these issues, this study focuses on vernacular houses in Japan and Britain, ${ }^{* 1)}$ because such structures share significant common ground, as they are constructed of timber frame, use exposed framing members as decorative elements, and are characterized by the traditional feature of a spacious central room (Japanese hiroma / British "hall"), which sometimes opens up to the roof. It is thus considered that terminology representing common architectural concepts may be grasped easily and effectively through comparison of the respective construction methods in the two countries, which themselves have a number of similarities.
A review of the extant studies on Japanese architectural terminology conducted by Japanese scholars reveals that there are no established standards for the terminology of timber members (the major components of these structures) or construction methods, compared with planning and architectural design, which are relatively easy to comprehend. In research on Japanese vernacular houses called minka, the pioneering guidebook How to Look at and Survey Minka, edited by the Japanese Agency for Cultural Affairs, ${ }^{1}$ provides a certain level of standards for related knowledge and skills. However, the glossary in the book does not contain a sufficient number of terms, and has not been revised for about 50 years. There are a number of other specialized glossaries (as described below), each with advantages and disadvantages, but no comprehensive compilation as of yet.

In Britain, Recording Timber-Framed Buildings: An Illustrated Glossary, published by the Council for British Archaeology2) (hereinafter referred to as 'the CBA glossary,' 'CBA,' or ' $\mathrm{C}$ ' in the tables in this paper), is the most practical and authoritative source, as it shows the relationship between terms and building systems, and clearly illustrates the members as components of a building. ${ }^{* 2)}$ However, there are slight differences
* Prof., Dept. of Forest Science and Resources, College of Bioresource Sciences, Nihon Univ., Dr. Eng.

** Assist. Prof., School of Design, Sapporo City Univ., Dr. Eng.
日本大学生物資源科学部森林資源科学科 教授 $\cdot$ 博士 (工学)

札幌市立大学デザイン学部＼cjkstart助教・博士(工学) 
in terminology in well-known publications, such as those by Brunskill and Harris (described below), and a comparative study would be of value.

More important to our study is the question of which English terms correspond to terms unique to Japanese. Existing English glossaries contain few translated terms for Japanese traditional architecture, $\left.{ }^{* 3}\right)$ though there are numerous English books on traditional Japanese architecture, and English translations of excellent Japanese books on the topic. However, in the latter, translators often do not choose the best English words for Japanese terms, in the context of the vernacular building system. ${ }^{*}{ }^{*}$

In this study, we focused on several reliable native-language glossaries compiled in the two countries (the Japanese glossaries contain supplementary materials to illustrate vernacular terms), avoiding overreliance on translated books and words. We identified images illustrating key terms describing the physical make-up of the respective buildings in each country, attempting thereby to avoid superficial correspondence between respective terms in the two countries. In short, this approach asks "What is this member called?" instead of "What does this word mean?"

The study discusses the main structural timber members of vernacular houses in Japan and Britain, which are fundamentally involved in the formation of structure and space, with the aim, first, of identifying the semantic range of terms for such timber members (not fully defined in previous studies), and

differences in the respective semantic ranges of similar Japanese and English terms; and second, of characterizing the arrangement of structural members and technical terms, based on the respective building systems.

Since this study deals with a very broad range of issues, the analysis divides buildings into several sections. This paper focuses on the main structural members of the understructure, also called the main structure, of one-story houses. The members of two-story houses, and of roof structures, will be discussed in subsequent papers.

\section{Method}

\section{2 (1) P rocedure for selecting materials for analysis}

Table 1 is a list of glossaries and publications to be analyzed. We first selected the above-mentioned CBA glossary, as the most authoritative British glossary, and then selected three other important sources: Brunskill's Timber Building in Britain 7) (hereinafter referred to as 'Brunskill,' or 'B' in the tables), which has an excellent illustrated glossary; Walker's glossary in his The English Medieval Roof - Crownpost to Kingpost ${ }^{8)}$ (referred to as 'Walker' or 'W'); and Harris' Discovering Timber-Framed Buildings 9) ('Harris' or ' $\mathrm{H}$ '), whose full text is valuable and respected source.

For Japanese technical terms, we selected four trustworthy glossaries for analysis: Kenchiku Daijiten [Encyclopedia of Architecture and Building] 10) (referred to as 'Daijiten' or 'D'), the

Table 1 Glossaries and publications

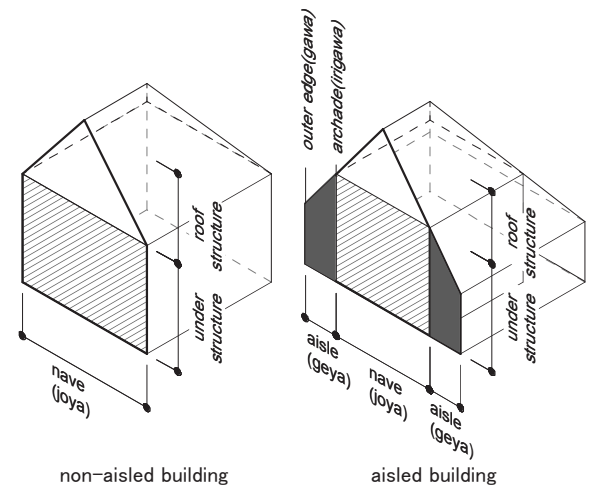

Fig. 1 Arrangement of a nave (joya) and aisles (geya)

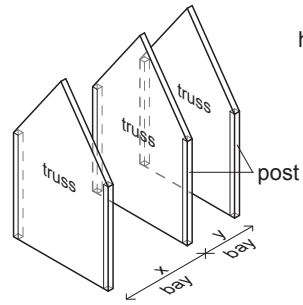

Britain

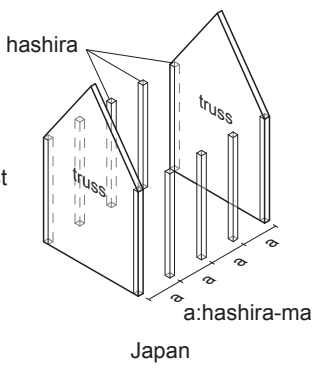
Japan
Fig. 2 Arrangement of trusses and bays

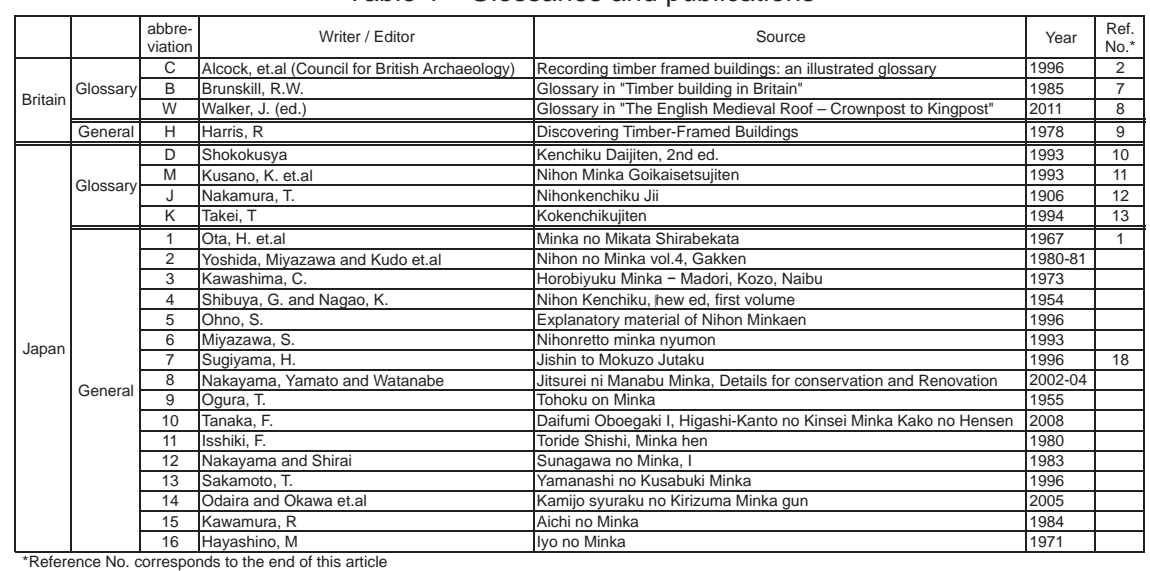

$\mathrm{O}$

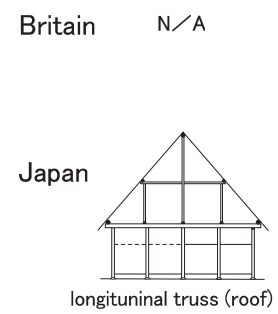$$
<
$$
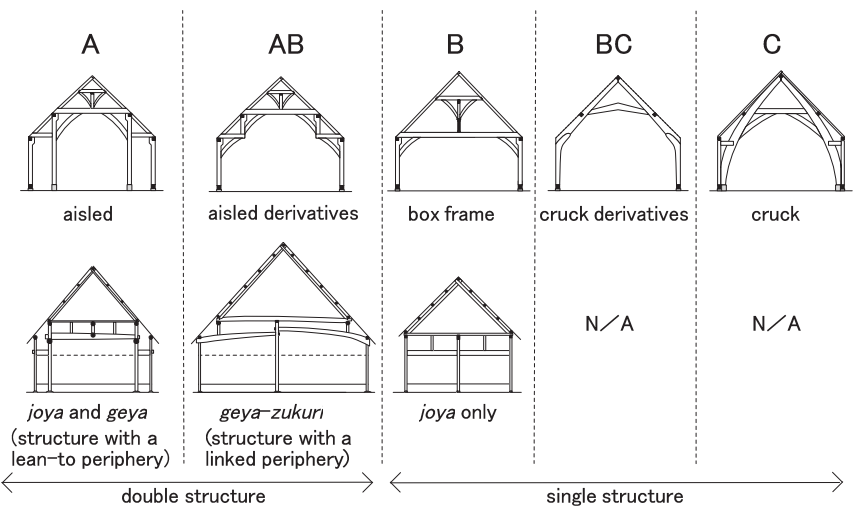

Fig. 3 Correspondence between timber-frame types in Britain and J apan 
most general dictionary; Nihon Minka Goikaisetsujiten [Glossary of Japanese Vernacular Houses (minka)] 11) ('Minkagoijiten' or ' M'), which contains a wide variety of terms for minka; Nihonkenchiku Jii [Japanese Terminological Dictionary of Architecture] 12) ('Jii' or 'J'), an established glossary of traditional architecture as a whole; and Kokenchikujiten [Terminological Dictionary of Historic Architecture]13) ('Kokenchikujiten' or 'K'), which covers traditional architecture in general, with concise text. However, as these glossaries do not provide sufficient information linking terms to illustrations, we also selected illustrations from 16 publications listed in Table 1.

\section{2 (2) Definition of terms and framework typology}

Before analyzing the meanings of framing-member terms, we must define the essential terms for frameworks and spaces, and outline the typology of diverse framing systems, in order to comprehend the relationship between the framework and the spatial configuration.

First, we will define the English nave (Japanese joya) and aisle (Japanese geya) (Fig. 1) as common concepts of framework and space. The nave (joya) denotes the central space and structural core of the building, formed by vertical members to support the roof structure. The aisle (geya), which is a side compartment running along the length of, or sometimes around the nave, denotes the area extending beyond the nave, under the eaves. Consequently, the uprights forming the structural framework of the aisle are lower in height than those for the nave. We also define the border of the framework. The Japanese gawa is the perimeter of the entire frame, while the Japanese irigawa which literally means "one row inside of the perimeter" corresponds to the British term "arcade," and means border between the joya (nave) and the geya (aisle).

Second, we define a truss and a bay as follows (Fig. 2). A truss is a rigid transverse framework spanning the roof at certain intervals. A British truss is typically a pentagonal structure which includes an understructure and a roof frame. In some cases, it is a triangular structure with a roof frame only. A Japanese truss is often not considered to be strongly connected to the understructure, but thought of instead as a roof-frame structure only. ${ }^{*}$ ) In this study, to compare Japanese and British frames, a Japanese truss is considered, in a broad sense, as a pentagonal structure that includes the members of the understructure.

A bay is the space between trusses in a timber-framed building. The Japanese bay, called hashira-ma, literally the "space between posts," resembles the British bay, but differs significantly in its use. ${ }^{* 6}$ ) Since British bays are sized appropriately for the room (usually a room is one or two bays wide), the bays are not necessarily of equal length (Fig. 2). Japanese bays, on the other hand, are of equal length, and work as a 'module' or unit of measurement for a room layout.
Next, we must describe the different types of framework, to determine how the respective members are defined in the given framework. Figure 3 compares common types of trusses in both countries. ${ }^{* 7)}$ British timber frames are usually divided into cruck and box frames, with box frames subdivided into aisled and non-aisled frames (Fig. 1). For the purposes of this study, we divide them into three primary groups ${ }^{*}{ }^{8}$ : aisled frames (A), box frames (B), and cruck frames (C). Additionally, we define an aisled derivative $(\mathrm{AB})^{*}$ ) as the intermediate type between the aisled frame (A) and box frame (B), and a cruck derivative (BC) ${ }^{*}{ }^{10)}$ as the intermediate type between the box frame (B) and cruck frame (C).

In Japan, there are basically three structural types: joya-only, joya and geya (a structure with a lean-to periphery), and the so called geya-zukuri (a structure with a linked periphery), ${ }^{* 11}$ ) which correspond to the British box frame, aisled, and aisled derivative, respectively (Fig. 3). There is also a further frame type only in Japan (Type O in Fig. 3), by definition a type of box frame, but with several longitudinal uprights rising to the ridge piece in the roof frame. It is thought that originally the uprights rose from the ground to integrate the understructure and roof structure. A framing system using "longitudinal trusses" is essentially different from other framing systems.

\section{Comparison between the English post and J apanese hashira 3 (1) Single terms for post and hashira}

As defined in the three Japanese glossaries in Table 2, the function of the hashira is not merely to support the roof and floor loads but also to transfer these loads to the foundation; the tsuka is defined as a shorter upright than the hashira. Thus, the Japanese word hashira clearly denotes something "long" and "rising from the ground."

The English post, ${ }^{{ }^{12} 2}$ meanwhile, is defined as a vertical member, a rigid structural member, or a load-bearing member, all of which apply to the Japanese hashira. However, the British glossaries do not state that the post must rise from the ground. In fact, vertical members, such as the hammer posts (No. 4 in Table 2) in a hammer beam truss are also termed posts, but do not rise from the ground. This indicates that the English "post" is used in a broader sense than hashira. Therefore the English post essentially corresponds to the Japanese hashira and tsuka.

Interestingly, Harris says that posts rise the full height of the frame. His definitions of posts and studs are very similar to the Japanese definitions of hashira and tsuka, in that a "post" is differentiated from a "stud" by its greater length. However, he also notes that a post is "in a wall frame," yet refers to an "inner post" isolated from the wall, which would appear to be contradictory. More importantly, the basic image of the British frame is a "wall" anchored by several "posts," whereas the Japanese frame does not involve the concept of a wall anchored 
in this manner.

3 (2) Compound terms with the English post and J apanese hashira

In this section, we discuss the meaning of compound terms with "post" and hashira. Table 2 shows that British wall and arcade posts correspond to various types of Japanese hashira. British arcade posts are used in a double structure composed of a nave (joya) and aisles (geya), shown as $\mathrm{A}$ and $\mathrm{AB}$ in Figure 3, and always stand inside. Wall posts, on the other hand, always stand outside a single structure (composed of a nave (joya) only) or a double structure.

The Japanese joya-bashira, a very commonly used term, is defined as a post supporting the main transverse beam which supports the roof. As a structural member, both the outside post in a single structure and the inner post in a double structure are called joya-bashira. Therefore, it is logically accurate to say that arcade post/wall post is more equivalent to irigawa-bashira/gawa-basira than joya-bashira/geya-basira, the more commonly used term pair.

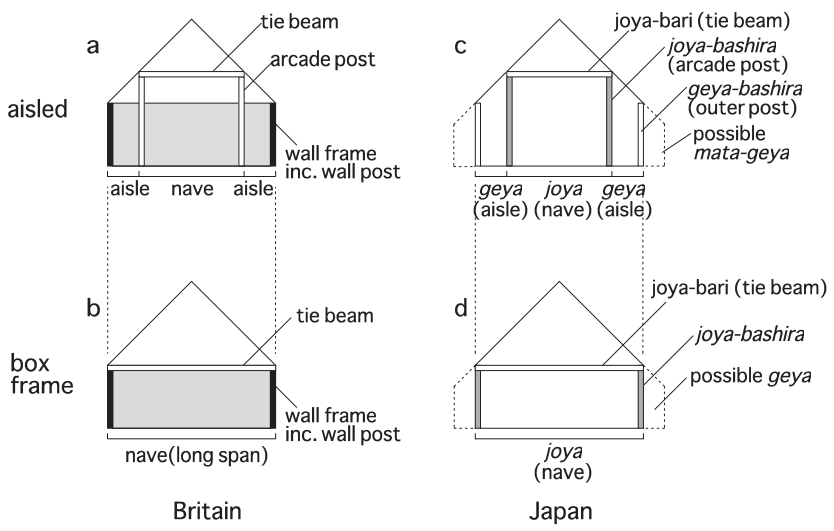

Fig. 4 Difference in the nave-aisle concept in Britain and J apan

Table 2 Terminology of posts (hashira) and their correspondence

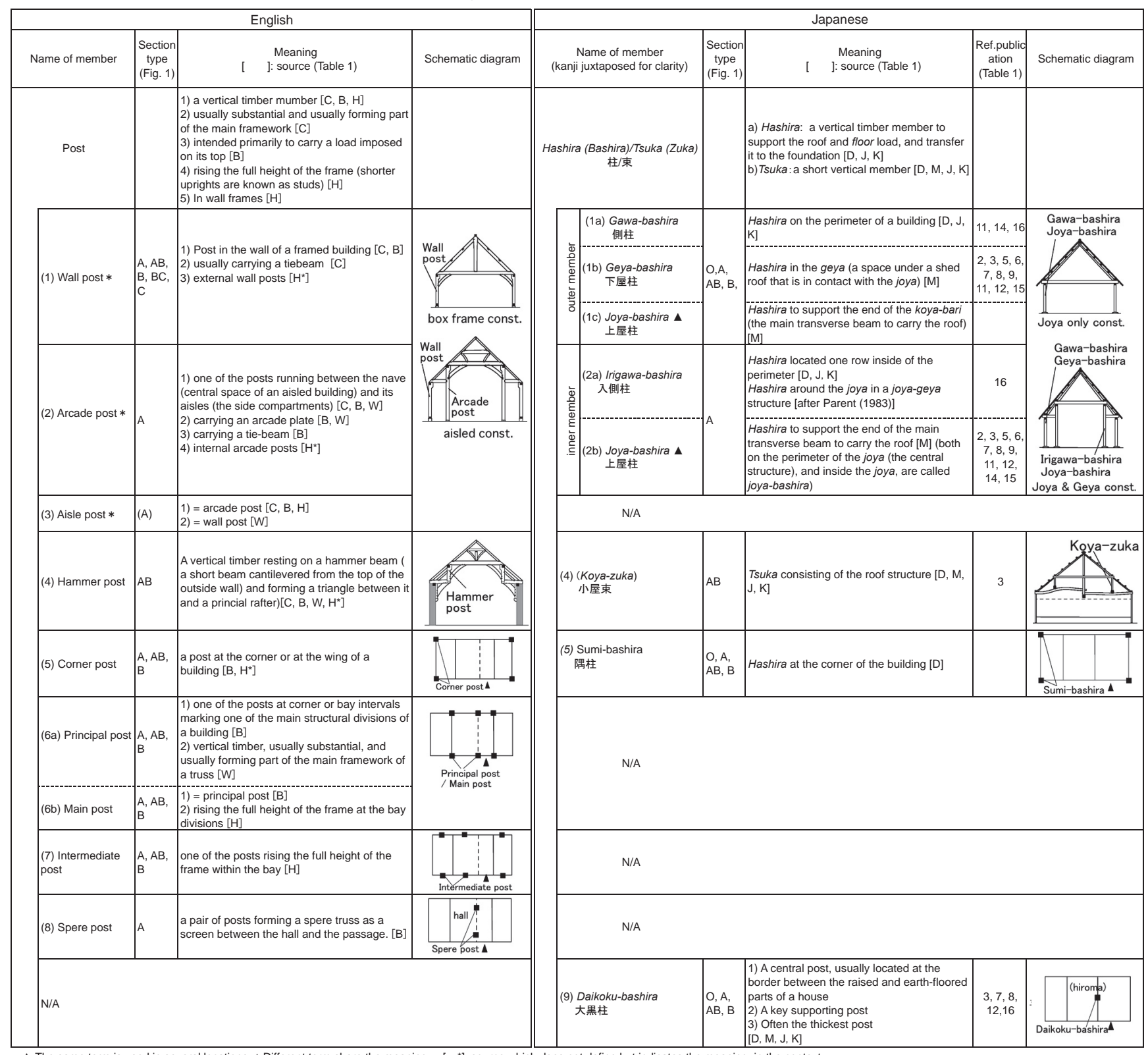

A The same term is used in several locations. * Different term share the meaning. [ *]: source which does not define but indicates the meaning in the context. 
This difference in meaning between the English arcade post/wall post and Japanese joya-bashira/geya-basira is due to the difference in the concept of a frame and space shown in Figure 4. In the British concept of a framework, walls are defined first, after which the other members, as well as their related terms, are defined. Japanese carpenters, on the other hand, do not think about walls in the first place. They take into account the possibility of setting mata-geya beyond the geya further outside. Subsequently they image an onion-like, multi-layered structure, built by adding aisles around a central core even in a simple frame consisting of a joya-only structure. (Fig. 4d).

Now let us consider an important post in spatial organization. As shown in No. 5 in Table 2, the most fundamental post is the British corner post and Japanese sumi-bashira. Both stand at the corners of a house or wing (the corner section of the house, adjacent to the main building). Neither of these are posts at the corners of a room. As shown in Nos. 6a and $6 \mathrm{~b}$ in Table 2, the second most important post in Britain is the "principal post" or "main post" in a bay and truss system. There are no corresponding terms for these in the Japanese glossaries, indicating that Japanese carpenters do not have a specific concept of posts related to trusses, but instead the concept of a "universal" post alone (Fig. 2). In English, a less important post is defined as an "intermediate post" (No. 7 in Table 2) set between bays. The Japanese glossaries contain no vernacular terms for the intermediate post, though the term is used by Japanese scholars in the academic context.

Finally, let us consider symbolic posts standing in particular positions. British spere posts (No. 8 in Table 2) are a pair of posts that form part of a spere truss as a divider between the hall and the passage. Occasionally, similar posts are erected in Japan, but their name has not been identified. The Japanese daikoku-bashira is a central post, usually located between the raised floor like hiroma and an earth-floored part of the house. There is no such central post, or name for such, in Britain.

\section{Comparison between the English plate and J apanese keta}

\section{4 (1) Single terms for plate and keta}

The English plate ${ }^{* 13)}$ and Japanese keta (geta) denote fundamental horizontal members in these houses. The terms correspond to each other, yet are very hard to define precisely, as each is used in a broad sense in their respective country.

Here we discuss the keta, using Table 3 and Figure 5. In Daijiten and Minkagoijiten, which give the narrowest definition of the term, it is defined as a member set on top of the gawa-bashira (perimeter post; A in Fig. 5). In Kokenchikujiten, it is defined as a member on top of the understructure, and its planar position is not specified. In a double structure, the keta can appear at both the gawa (A) and irigawa (B) positions, as shown in Figure 5. In Jii, which gives the broadest definition, it can be placed on top of the hashira, tsuka, or wall, and the height of the keta is not specified. The keta can even be placed at positions C or D (the top of the roof), as shown in Figure 5. ${ }^{* 144}$. The broader definition of the term renders the concept of keta complex, because specifying the gawa position (perimeter) is clearly contradictory to allowing the keta to be placed anywhere along the roof slope. ${ }^{* 15)}$ With the broader interpretation in Jii, the keta is allowed to be placed on top of a free-standing post or wall, without being placed along the wall or roof slope (E in Fig. $5)$.

The English "plate" is notably different from the Japanese keta, in that it is used in a broader sense. The definition of the plate is given in three publications. Only CBA defines the plate as a longitudinal timber member, likely because CBA has gable roofs in mind, which are common in Britain; whereas Brunskill and Harris seem to allow the plate to be placed crosswise, likely because they have radial roof structures such as hip roof and gambrel roof in mind. Interestingly, in CBA, the plate can be located only on top of the wall or in the roof truss. Brunskill and Harris do not specify the position of the plate. Harris clearly states that the plate can be located either at the head or foot of the frame, in distinct contrast to the definition in CBA, revealing a fundamental inconsistency in the understanding of the term "plate" in the British framing system.

Concerning the cross-sectional dimensions of the plate, Brunskill notes that the plate is usually rather wider than deep in proportion, a reasonable assertion given that the plate is, unlike the beam, actually supported by several vertical members, and thus not required to bear a superimposed load. As an additional specification concerning the placement of this member, CBA points out that it is set square to the ground, while a purlin is set in the plane of the roof slope; an important distinction for understanding the characteristics of the plate as a member of the understructure, as opposed to the purlin as a member of the roof. *16)

\section{4 (2) Compound terms with plate and keta}

Now let us consider compounds based on the terms "plate" and keta. Table 3 shows that the arcade plate is located inside, and the wall plate outside, regardless of whether the frame is aisled or non-aisled; in the same manner as the use of "wall" and "arcade" in the compounds with "post" (and Japanese correlatives with hashira).

As with the "post" compounds, the Japanese joya-geta and geya-geta do not necessarily correspond to the British terms "arcade plate" and "wall plate". As shown in Table 3, the Japanese terms corresponding to the British "wall plate" are: (1a) the single term keta with no prefix, (1b) the compound term gawa-geta (gawa means "perimeter"), (1c) the compound term geya-geta (geya is equivalent to "aisle"), and (1d) the compound term noki-geta (noki means "eaves"). 
Some confusion is apparent in the terminology, but in sum there are two main options for how to use the single term keta in a double structure: consider the inside member as the keta, with emphasis on the joya (nave), or consider the outside member as the keta, with emphasis on the gawa (perimeter).

In fact, there are many different Japanese combinations corresponding to the English terms "wall plate" and "arcade plate," making it difficult to identify especially significant compounds. In this paper, as with the "post" compounds, the prefix gawa (perimeter) is used to indicate that the keta is located outside, and the prefix irigawa (inside) is used to indicate that the keta is located inside. We specify the gawa-geta as a wall plate, and the irigawa-geta as an arcade plate (the latter is not found in the glossaries in Table 3, but in Parent (1983) 6)).

The British "template" and "sole plate" (Nos. 4 and 5 in Table 3) are both used when the timber roof structure rests on masonry walls; and there are no corresponding members in Japan, where the understructure is constructed of wood. It is interesting that the sole plate runs crosswise because of the wall thickness, whereas the plate is normally set longitudinally. In this case, the characteristic of the plate, as "rather wider than deep in proportion" (Brunskill), is emphasized.

While the compound terms "post plate" (or "bottom plate") and "roof plate" (or "top plate") (Nos. 6 and 7 in Table 3) incorporate Harris' notion of the plate "at the head or foot of a frame," the latter is also called a "sill beam," with the root word "beam," though it should be logically called a "plate" because a structural member (the post) rises from it.
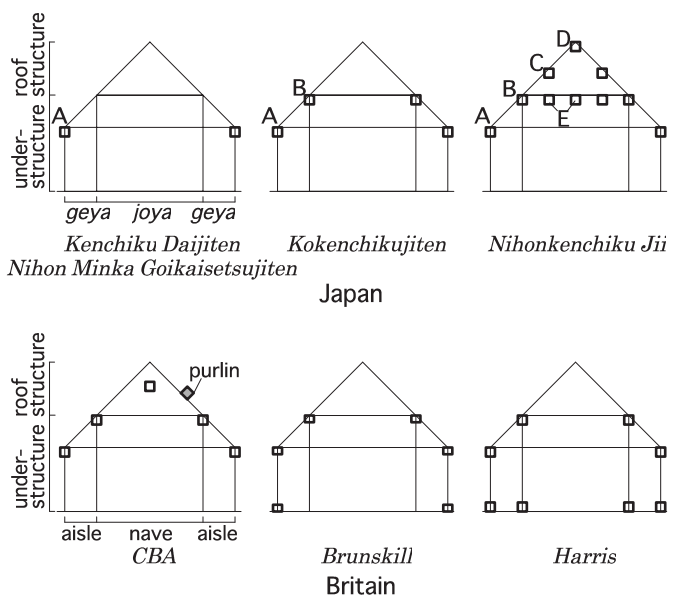

Fig. 5 Position of plates (keta) suggested by the glossaries

Table 3 Terminology of plates (keta) and their correspondence

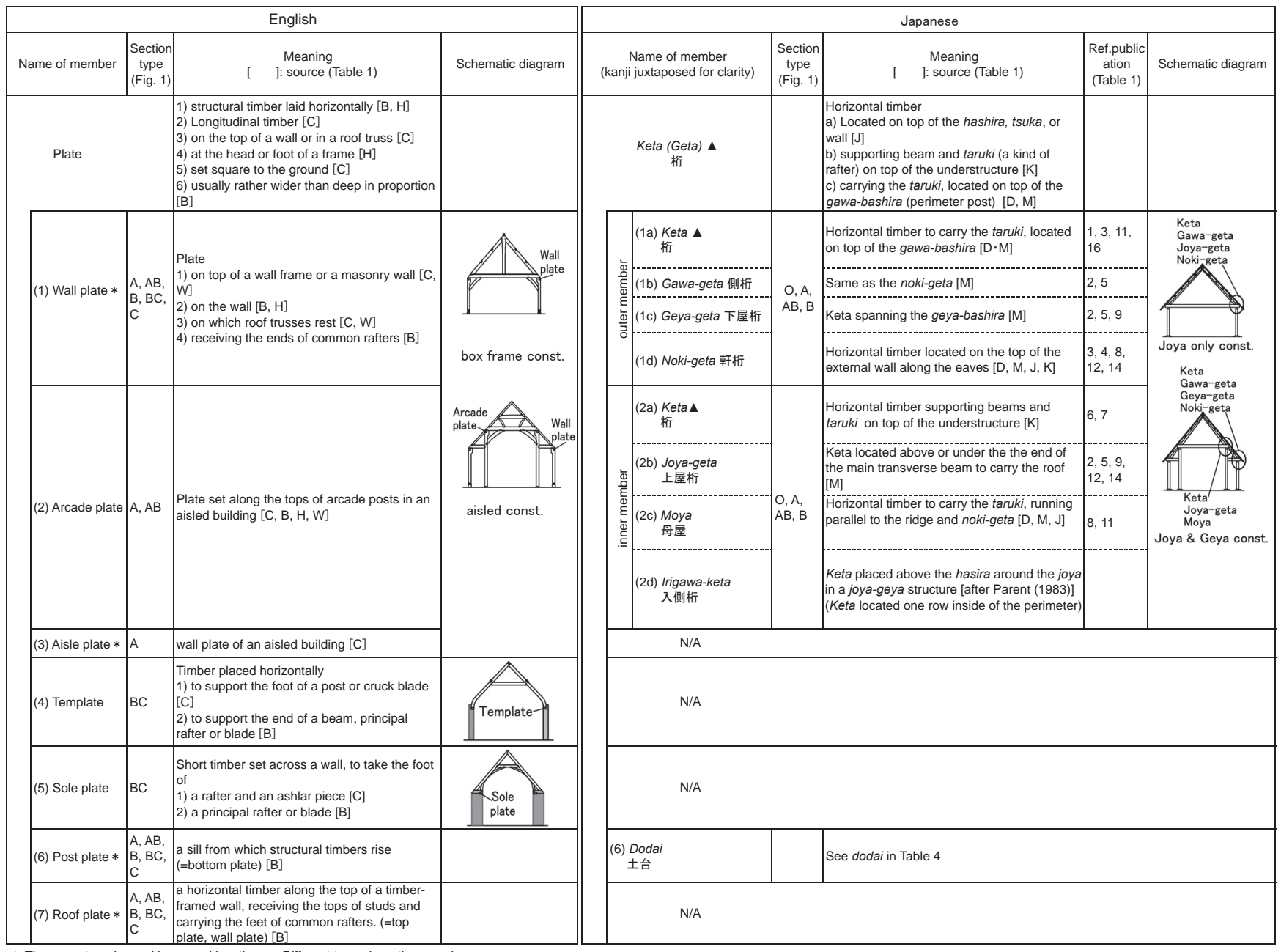

The same term is used in several locations. $*$ Different term share the meaning. 
5. Comparison between the English beam and J apanese hari 5 (1) Single terms for beam and hari

Like plate and keta, the English beam*17) and Japanese hari (bari) are fundamental terms for horizontal members. Table 4 shows the definition of a beam in two British glossaries. In the glossaries, a beam is defined as a major horizontal structural member tying two members together and bearing a superimposed load, but there is no description of the beam height or joints. The semantic range of the Japanese hari differs among the glossaries. There, the hari (as a single term), like the English "beam," bears a general load, as well as the load from the roof structure; but the hari is specifically placed on top of the hashira (post) (Fig. 6a), on the side of the upper part of the hashira (Fig. $6 \mathrm{~b}$ ), or on the keta (plate) (Fig. 6c). Thus, the Japanese hari is

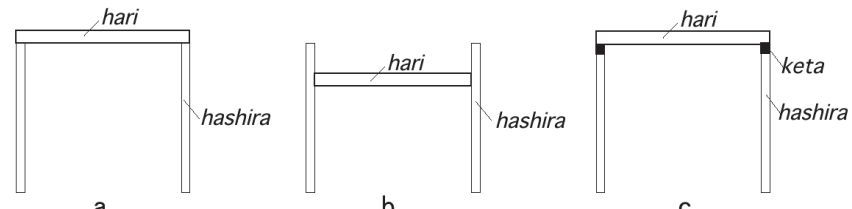

Fig. 6 Positional relationship of the hari (beam) and other

Table 4 Terminology of beams (hari) and their correspondence

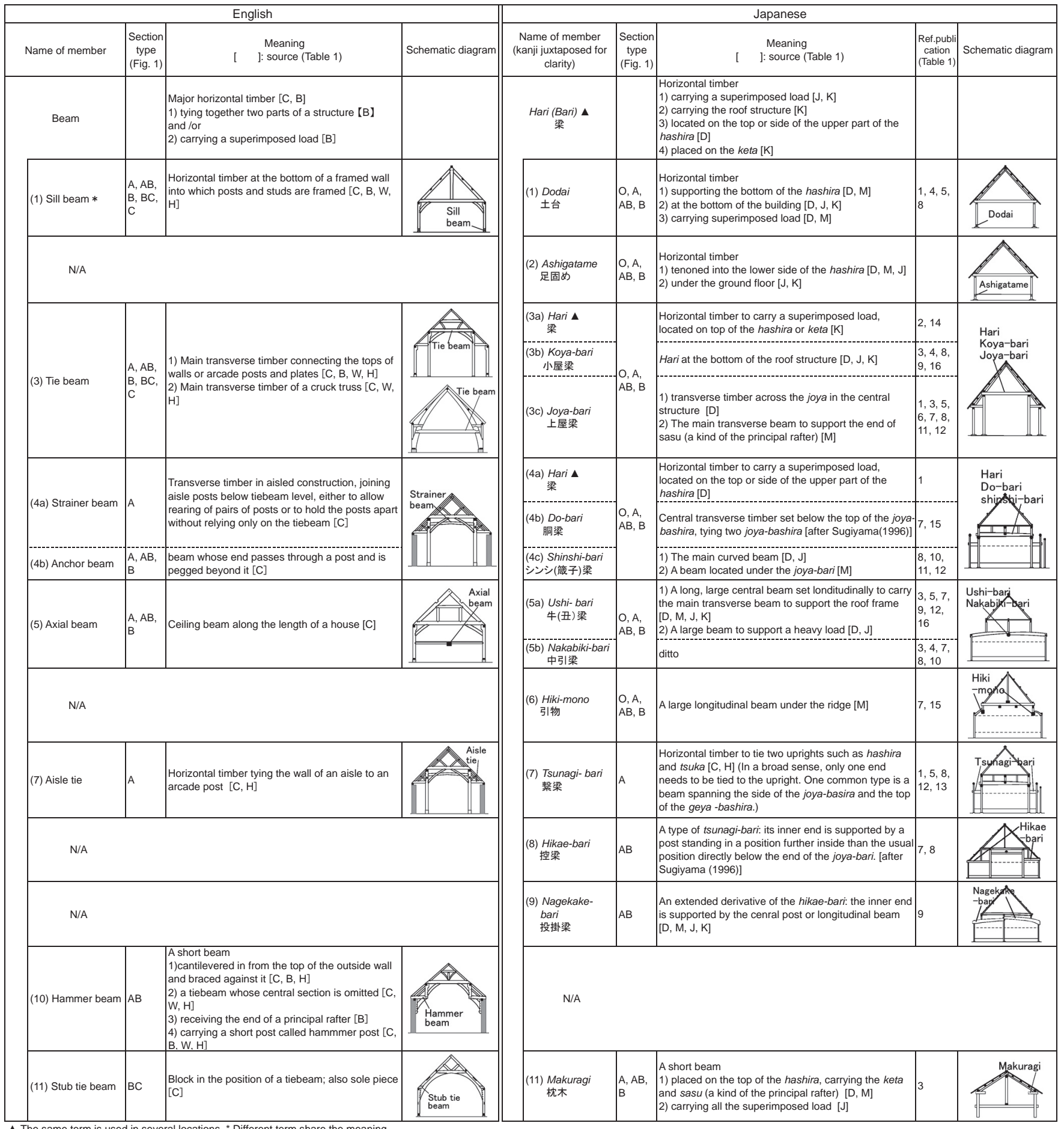


characterized by its relationship with other members supported by it, whereas the English "beam" is more simply defined.

\section{5 (2) Compound terms with beam and hari}

Now let us consider relevant compound terms. As previously mentioned, Brunskill defines the "sill beam" (No. 1 in Table 4) as a type of plate. This member is well translated by the single Japanese term, dodai, which is not a compound rooted in "beam" or "plate." The term "ashigatame" (No. 2 in Table 4) is seemingly akin to dodai but the former is set on the lower side of the post usually under the ground floor. We cannot find such a member in the British glossary.

The most important "beam" compound is "tie beam" *18) (No. 3 in Table 4), a difficult term, with two different meanings depending on the frame type. In types $\mathrm{A}, \mathrm{AB}$, and $\mathrm{B}$ (Fig. 3), it means the main transverse timber tying together walls, arcade posts, and arcade plates. In this case, it is considered as a member bordering the roof structure and understructure. While there is no description of the height of the main beam in a cruck truss, which appears in BC and C (Fig. 3). A beam set below the top of the wall plate, as shown in No. 3 in Table 4, is also called a tie beam; ${ }^{*}{ }^{19)}$ and this fact suggests that tie beams are framed without a height limit, because the cruck frame is a framework in which the understructure and roof structure are not separated.

Japanese compound terms corresponding to the first sense of "tie beam" are diverse (Nos. 3a, 3b and 3c in Table 4). The English term may simply correspond to hari with no prefix, to the Japanese koya-bari (koya means a roof frame), or to joya-bari (joya originally meant the span of the main roof). On the whole, we consider joya-bari the best correlative, because hari is ambiguous and koya-bari does not always indicate the top of posts but is rather higher or lower in some cases.

The British "strainer beam" (No. 4a in Table 4), also called an anchor beam, is a transverse beam whose end is tenoned into the side of the upper part of a post. This member is very popular in Japan. It corresponds to the hari with no prefix, or the do-bari or shinshi-bari (Nos. 4a, 4b and 4c in Table 4).

In Japan, there are several types of beams set longitudinally, to tenon the side of the upper part of a post. The central beam is called the ushi-bari or nakabiki-bari (Nos. 5a and 5b in Table 4). It supports a heavy load, and often joins the daikoku-bashira and the same types of post together. There is no English term that exactly corresponds to the Japanese ushi-bari or nakabiki-bari. The British "axial beam", a type of floor beam, is laid in the same position; however, the Japanese beam in this position typically does not support the floor, but merely carries the roof frame. This difference in framing method leads to significant spatial appearance between vernacular houses in Britain and Japan. ${ }^{* 20}$

Another beam, called the hiki-mono (mono basically means hari) (No. 6 in Table 4), is located on the border between the joya and geya, far from the backbone of the framework. There is no such beam type, or term, in the British framing systems.

Now let us consider the variation in the form of the nave and aisles in aisled construction. The British "aisle tie" (No. 7 in Table 4) is an abbreviation for "aisle tie beam," which acts like a "tie beam" spanning the width of the aisle. The corresponding Japanese term, tsunagi-bari, is used in a much broader sense, with its function simply being to tie together two uprights, regardless of its height and placement. One common type, spanning the joya-bashira and geya-bashira, is equivalent to the British aisle tie; but another type, called hikae-bari (No. 8 in Table 4) ${ }^{* 21)}$ ), is longer because its inner end is supported by posts standing further inside than the usual position directly below the end of the joya-bari. A more advanced type is the nagekake-bari (No. 9 in Table 4), whose inner end reaches the central post or a beam called the ushi-bari (mentioned above). It is noteworthy that diverse Japanese techniques, such as those involving the hikae-bari (a type of tsunagi-bari) and nagekake-bari (an extended derivative of the hikae-bari), which are often referred to as "taking geya inside" to make structure with a liked priphery, are not used in Britain.

In the above, we gave an example in which arcade posts are moved inward. Now, we shall give an example in which arcade posts are eliminated. The British "hammer beam" (No. 10 in Table 4) is a short beam cantilevered in from the top of the outside wall, and braced against it in order to eliminate an arcade post. It is also regarded as a tie beam whose central section is omitted. In Japan, there is no similar frame member to the hammer beam. However, there is a shorter hammer beam, called a "stub tie-beam" (No. 11 in Table 4), which is a block in the position of a tie beam; and this corresponds to the Japanese makuragi, which is a very short member like the stub tie-beam, and carries the roof truss.

\section{Comparison between British and J apanese curved timbers}

A cruck is the most well-known British curved timber. Its definition, however, is complicated, as shown in Table 5. All four glossaries describe a pair of long opposing timbers being framed together; beyond this, however, the details differ. ${ }^{* 22}$

The most essential definition of the cruck is given by Harris, who describes its placement simply as "rising from ground level," and notes, in terms of the framing system, that it is "joined by a tie beam or collar ${ }^{* 23)}$ (a transverse timber set in the roof truss) and "supports the roof purlin *23) (a longitudinal timber set in the plane of the roof slope). This description reflects precisely its characteristic of being a member of both the understructure and roof structure.

Both joined and base crucks (Nos. 1 and 2 in Table 5) are forms unique to Britain, where further short-cut timbers are combined to create a cruck-like shape. The compound term 
"jointed cruck," shown as type BC in Figure 3, denotes two timbers joined together by a joint in the roof frame. The "base cruck," (No. 2 in Table 5) is regarded as one of the "aisled derivative," shown as type AB in Figure 3, because it is placed to omit an arcade post. It appears a cruck whose blades reach as high as the first transverse member, usually a tie beam.

Such framing forms are rarely found in Japan. The Japanese mata-bashira (No. 2 in Table 5) is similar to the British base cruck, but different in detail. The base crucks are usually framed together transversely in pairs, and the horizontal distance between the bottom and top of the curved timber is quite long. The mata-bashira, on the other hand, is used alone and curved in the longitudinal direction, and the distance between the bottom and top of the curved timber is very short.

When we look at a curved timber close to a beam, we can find the Japanese chona-bari ${ }^{* 24)}$ (No. 3 in Table 5), a transverse beam with a natural downward curve at the outer end. The Chona-bari is regarded as a type of nagekake-bari (No. 9 in Table 4). In Table 5, Chona-bari beams are arranged symmetrically in pairs, and can be placed alone on one side to omit a specific irigawa-bashira (arcade post).

A British framing member similar to the Japanese chona-bari is the "extended arch brace" ${ }^{* 25)}$ (No. 3 in Table 5), which supports the roof load in place of arcade post. In this case, a brace, which is usually used as a reinforcement, is functioned as a beam.

\section{Conclusions}

We have identified key characteristics of the arrangement and terminology of British and Japanese vernacular timber house frames, based on the principles of the respective building systems, and these are summarized below.

The English "post" and Japanese hashira have similar but slightly different semantic ranges, with the latter, as a single term, having a narrower sense. The meaning of English post covers those of Japanese hashira and tsuka. The English posts are basically regarded as the elements of the wall but Japanese hashira is free from the wall. Consequently there is a notable difference in meaning of compound terms in the case of a double cross-section.

The English "plate" and Japanese keta are similar in having a broad semantic range with more than one meaning. The Japanese keta means a horizontal member running along the top of the uprights either outside or inside of the building in the broadest sense, whereas the English term "plate" has a broader semantic range, which includes the member located either at the head or foot of the frame.

The English "beam" resembles the Japanese hari, but is used in a narrower sense. With regard to compound terms, the British beam is obviously part of a truss and essentially set only crosswise, while the Japanese beam spans both crosswise and lengthwise. Thus, there is a much wider variety of Japanese beams, and an equally wide variety of compound terms involving beams.

Comparing British and Japanese curved timbers, the former are typically framed symmetrically in pairs, with consideration of the shape of the truss as a whole; whereas the latter are typically arranged one by one in a supplementary manner, without consideration of the framework as a whole.

\section{Notes}

*1) This paper focuses on England and Wales (hereinafter referred to as "Britain"), and excludes Scotland and Northern Ireland due to the relative scarcity of timber-framed buildings in these regions.

*2) For this reason, the British academic journal Vernacular Architecture recommends that authors use this glossary.

*3) Concerning Japanese Scientific Terms, Architecture ${ }^{3)}$, Hideo Moriya, who organized the preparation of the draft, has noted that, unlike other academic fields, governed by international standards, Japanese architecture tends to be influenced by the culture, nature, and society

Table 5 Terminology of curved timbers

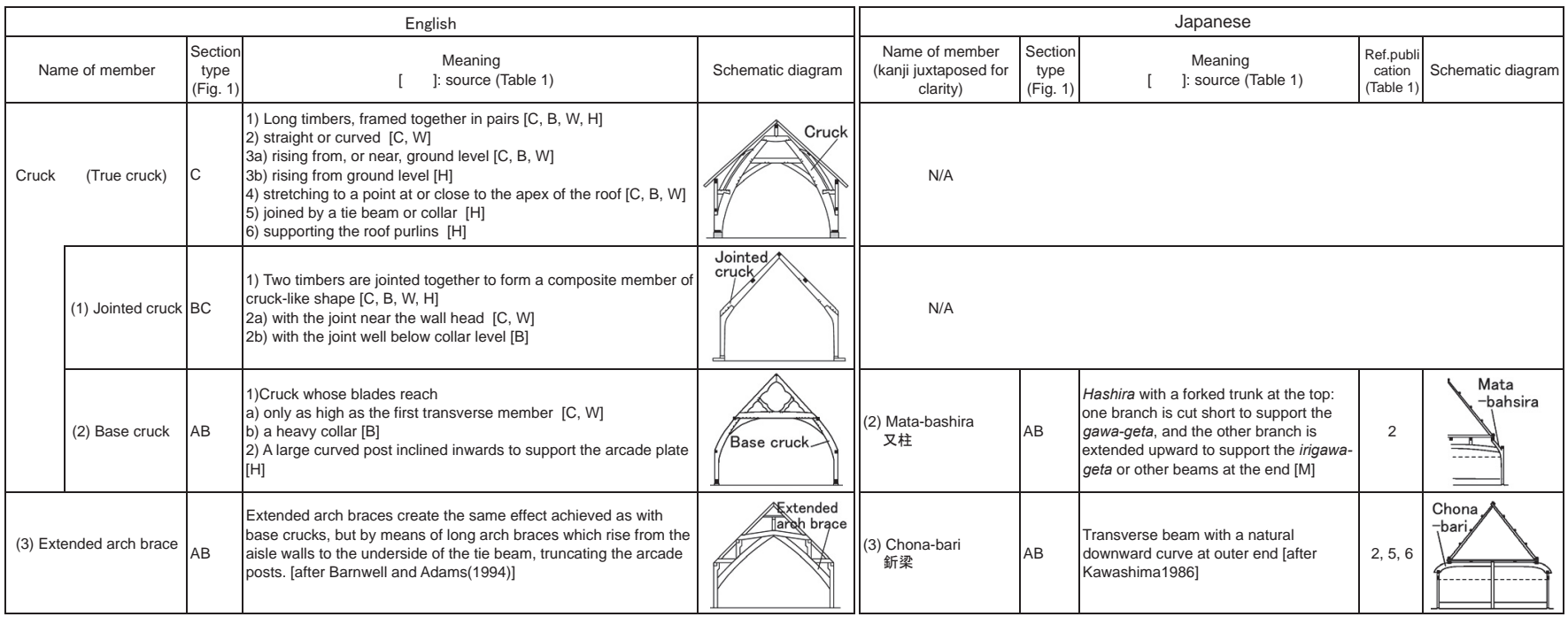


of Japan; and he and the co-authors did not attempt to translate historical architectural terms. (Moriya(1991)) ${ }^{4}$

*4) For example, Kawashima (1986) 5) seems to give useful information, but has some keywords mistranslated (how they have been mistranslated is interesting from a cultural perspective). While Parent (1983) ${ }^{6)}$ includes an excellent glossary of terms juxtaposing kanji for clarity. It focuses on Japanese temples and shrines, which are different in tradition from minka. Therefore, to avoid confusion, we did not use this work unless needed.

*5) It should be noted that the concept of "truss" has been misinterpreted, due to misunderstanding or narrow understanding of the term by Japanese scholars and engineers.

*6) Morris (1988) ${ }^{14)}$ refers to the difference in the use of the terms "bay" and ken.

*7) This classification into the five categories has been verified by Horie (2009a ${ }^{15)}$ in view of the cases of both Japan and Britain.

*8) There is a slight difference in the wording between Figure 8 on page 11 of Harris (1973) ${ }^{9)}$ and Figure 2.1 on page 15 of Roberts (2003) 16); however, both books show the same classification of three types.

*9) This term is quoted from page 76 of Smith (1955) ${ }^{17)}$ and page 7 of Roberts (2003).

*10) This term is quoted from page 1 of Charles (1967) ${ }^{18)}$.

*11) These three categories are based on Horie (2009b). 19)

*12) Jananese glossaries Kenchiku Daijiten and Nihonkenchiku Jii both indicate that Japanese hashira corresponds to "column" and "pillar" as well as "post". However none of the three glossaries in Table 1 list these two terms as headwords. In addition Harris (1973) 9) always uses the term "post" for hashira over the entire page except at only two general descriptions in the beginning part where he used "column". Therefore "column" and "pillar" do not have to be considered as technical terms for the vertical member in traditional timber-framed construction.

*13) Kenchiku Daijiten shows that Japanese keta corresponds to "girder" as well as "plate". However both glossaries of CBA and Brunskill regard "girder" as a member carrying the upper floor. It is considered to be Japanese dozashi rather than keta. Thus the term "girder" is not applicable.

*14) In fact, there is wording such as muna-geta and moya-geta.

*15) This is likely the reason why keta was translated as "purlin," instead of "plate," in Kawashima (1986) 5) and Parent (1983) 6).

*16) This distinction will be discussed in detail in the next paper, which will focus on roof frames.

*17) Kenchiku Daijiten also shows "girder" and "joist" as the English equivalent of Japanese hari. However both glossaries of CBA and Brunskill regard them as members that carry the floor, indicating a narrower sense than that of hari. Thus these terms are not applicable.

*18) In the CBA glossary, the unhyphenated "tiebeam" is used, instead of "tie beam," due to its significance.

*19) We confirmed this through interviews with two well-known British researchers, R. A. Meeson, who was one of the compilers of In the CBA glossary, and Jane Grenville.

*20) In the interview with R. A. Meeson, we found that the term "spine beam" (corresponding to the Japanese ushi-bari or nakabiki-bari) had once been used, but the term was too minor to be included in the glossaries.

*21) Not explained in the four Japanese glossaries, but illustrated in other publications such as Sugiyama (1996) ${ }^{20)}$.

*22) A detailed explanation was required, from an academic perspective, to interpret a variety of frame forms besed on "cruck." See Ref. 21.

*23) This is a member of the roof structure, and will be discussed in the next paper.

*24) This wording is used in Kawashima (1986) 5).

*25) This term is not contained in the glossaries used in this paper. Barnwell \& Adams (1994) ${ }^{22)}$ took notice of the term and used it.

\section{References}

1) Ota H. et al (eds) :Minka no Mikata Shirabekata (How to Look at and Survey Minka), Agency for Cultural Affairs, 1967.10

2) Alcock, N.W., Barley, M.W., Dixon, P.W. \& Meeson R.A. : Recording Timber Framed Buildings: An Illustrated Glossary, Council for British Archaeology Practical handbook 5 (revised edition), London, 1996

3) Gakujutu Yogosyu (Japanese Scientific Terms, Architecture) enlarged and revised edition, Ministry of Education Science and Culture Japan, Architectural Institute of Japan, 1990.4

4) Moriya, H. : 'The problems of technical terms in view of editing Japanese Scientific Terms, Architecture', The journal of Information Science and Technology Association, vol.41 No.4, pp.344-350, 1991.4

5) Kawashima, Chuji : Minka : Traditional Houses of Rural Japan, translated by Lynne E. Riggs, Kodansha International, Tokyo \& New York, 1986

6) Parent, M. N. : The Roof in Japanese Buddhist Architecture, Weaterhill / Kajima, New York \& Tokyo, 1983

7) Brunskill, R.W. : Timber Building in Britain, 2nd edition, London, Victor Gollancz, 1994

8) Walker, J. (ed.) : The English Medieval Roof - Crownpost to Kingpost, Gipping Press, Suffolk, 2011

9) Harris, R. : Discovering Timber-Framed Buildings, Shire Publications, Princes Risborough, 1978

10) Aoki, S. et.al (eds) : Kenchiku Daijiten (Encyclopedia of Architecture and building, second edition), Shokokusya, 1993.6

11) Kusano, Kazuo (eds) : Nihon Minka Goikaisetsujiten (Glossary of Japanese vernacular houses (minka)), Nichigai Associates, 1993.9

12) Nakamura, T. : Nihonkenchiku Jii (Japanese Terminoloical Dictionary for Architectures), Maruzen,1906.6 (newly revised edition, Chuokoron art publication, 2011.10).

13) Takei, T. : Kokenchikujiten (Terminoloical Dictionary for Historic Architectures), Rikogakusya, 1994.5

14) Morris, M. : Japanese and British Folk Houses of Four Centuries Ago: Two Countries Viewed by Anjin Miura, Journal of Architecture and Building Science, Vol. 103, No. 1280, pp. 50-53, Architectural Institute of Japan, 1988.12

15) Horie, $T$ (2009a): 'Differing approaches to the elimination of arcade posts in the timber-framed open halls of Britain and Japan', Vernacular Architecture 40, 75-90, 2009

16) Roberts, E. : Hampshire Houses 1250-1700. Their Dating and Development, Hampshire County Council, Winchester, 2003

17) Smith, J.T.: 'Medieval aisled halls and their derivatives', Archaeol $J$ 112, 76-94, 1955

18) Charles, F.W.B.: Medieval Cruck-Building and Its Derivatives, Society for Medieval Archaeology Monograph, 2, 1967

19) Horie, T. (2009a) : 'Typology of the framework systems in the Minka, Japanese vernacular houses, A methodological study on the extent of repetition of the core frame style and the correlation between the central and peripheral structures', Journal of Architecture and Planning (Transaction of AIJ), vol. 74, No. 645, pp.2389-2397, 2009.11

20) Sugiyama, H. :, Jishin to Mokuzo Jutaku (Earthquake and timber-framed house), Maruzen, 1996.7

21) Smith, J.T.: 'The problems of cruck construction and the evidence of distribution maps', in N.W. Alcock (ed.), Cruck Construction: An Introduction and Catalogue, CBA Res Rep 42, 5-24, 1981

22) Barnwell, P.S. \& Adams, A.T.: The House Within: Interpreting Medieval Houses in Kent, Her Majesty's Stationery Office (HMSO), London, 1994 


\section{和文要約}

\section{1. 研究の動機と目的}

建築用語は、現代建築はもちろん伝統建築の構法を理解するうえ で最も基底となる概念であるが、日本の伝統的建築の語彙は母国語 での整備が遅れており、外国語とくに英語への翻訳という点での体 系的な検討は手つかずになっている。こうした問題を解決する端緒 として、本研究は、日英の伝統的民家の木造架構において、建築の 構造や空間に深く関わっている主要構造部材を取り上げ、これまで の研究で充分に表現されていなかった部材用語の意味の範囲と食い 違いを明らかにし、また建築構法に基づいた構造材の配置と術語の 特質を解明することを目的としている。

\section{2. 研究方法}

\section{(1) 分析資料の選出}

イギリスの著名な用語集およびこれに類する文献計 4 点および日 本の用語集 4 点を取り上げた。日本に関しては他に 16 文献から図 説を補足資料として加えた。

\section{（2）基本用語の定義と日英の断面系統}

共通する架構-空間概念として、まず建物の架構および空間が二重 構造になっているものに関して、中央部分を上屋 (nave)、周縁部分 を下屋（aisle）とした。次いで、truss と bayに関して以下のように 定めた。truss は一定間隔で棟木を横切って立ち上がる構造面であ り、小屋組だけに偏りがちな日本語の「トラス」より広義に、軸組 部分も含めたものとした。bay は truss 間に挟まれた部分で「柱間」 に対応するが、日本の「柱間」が、イギリスのbayとは、その使い 方の原理において異なることを示した。

\section{3. 英語の「post」と日本語の「柱」の比較}

post と柱はおおむ称同義のものとして対応寸るが、若干意味の広 さに違いが見られた。堅固な垂直材で荷重支持を旨とする点は共通 するが、日本における柱はその定義において、長く、地面を起点に することが強くイメージされている点が異なる。したがって post は柱と束を合わせた概念であるといえる。また英語の post は基本的 に壁を構成する一要素としてとらえられているのに対し、日本の柱 は壁の概念から無縁である。その結果として上屋 (nave) と下屋 (aisle)の二重構造になった場合の日英の名称にずれが生じている。

また平面上では、イギリスでは bay と truss のシステムに従い、 階層的に名称が与えられるが、日本では架構区画の構面間に立つ柱 は基本的に等価と見なされている。役柱に関しては、イギリスの spere post、日本の大黒柱のように、固有の背景から独自の柱とその 名称が生じている。

\section{4. 英語の「plate」と日本語の「桁」の比較}

plate と桁は、両国それぞれにおいて辞書による語義の範囲の違 いが大きく、意味の広さの解勫が難しい部材である。日本では最広 義で垂直材の上辺を繋ぐ水平材までを含める解勫があった。日本の 桁では、柱頭と屋根勾配面の各所において語義の多様性が生じてお り、その多様さの理解として、上屋を優先して内側にあるものに単 純呼称「桁」を宛てる考え方と、側を優先して外側にあるものを「桁」 と解釈する考え方の 2 種が併存していることがわかった。

英語の plate は、小屋組にあっては屋根勾配面に対する部材の置 き方によってそのように呼ばれないこともあるが、一方で架構の上
端のみならず下端に設けられるものまでを含めるほどの語義の広が りが認められた。

\section{5. 英語の「beam」と日本語の「梁」の比較}

英語の beam が繫ぎと荷受けという基本的な定義であるのに対し て、日本の梁は他部材との取り合いや接合の点で、柱頭に直接また は桁を介して載る、柱側面に取り合う、などの部材の位置関係の多 様さを意識した定義がなされている。

梁の複合語については以下のような特質を指摘できる。ひとつは、 梁行の最も基幹的な梁に対する概念に際立った違いがあった。イギ リスの tie beam は様々なトラスのなかにあって、とくに cruck 架 構においてその高さが流動的である。一方、日本の上屋梁は軸・小 屋を境界にあって固定的である。

もうひとつは、bay と truss の配置の違いによる架構の多様さの 違いである。イギリスには桁行梁がほとんど存在しないが、日本で は桁行にも多様な梁が存在し、また名付けられている。またイギリ スでは nave と aisleによる二重架構における梁行方向の構成が単純 だが、日本では上屋・下屋境以外の位置にも柱が立つことにより、 種々の形態の梁が現れている。

\section{6. 曲がり材に関する日英比較}

曲がり材を比較すると、イギリスでは基本的に post の変種として 側から棟に向けて長大な湾曲材を用いた cruck と呼ばれる構法をも とに、その湾曲材が様々な形で分節した変化形が展開している。こ のうち base cruck が、日本の又柱との類似性を示していた。また、 柱由来とは異なる特殊形としてイギリスの extended arch brace や 日本の釿梁が挙げられる。

\section{7. 結論}

建築構法の原理に基づいた日英における伝統木造架構の部材配置 と用語法の特質が以下のように抽出された。

post と柱は、単純語においては、似ているが若干意味の広さに違 いが見られ(後者のほうが狭い)、post は柱と束を合わせた意味とい える。また英語の post は基本的に壁を構成する一要素としてとらえ られているのに対し、日本では壁の概念から無縁である。その結果 として断面構成が二重の場合に複合語の意味のずれが生じている。

桁と plateの語義は、ともに意味が限定されず広い点が共通して いる。日本では最広義でも垂直材の上辺を繋ぐ水平材というところ までであるのに対して、イギリスではさらに広義に、架構の上端と 下端までを含んでいる。

英語の beam は日本の梁より意味が狭い。複合語で見ると、イギ リスでは beam がトラスの一部として位置づけられ、基本的に梁間 方向にのみ現れている。一方、日本では梁が梁間、桁行両方向に現 れる。それゆえ日本の梁の種類はイギリスよりずっと多く、また梁 に関連した複合語も多様である。

曲がり材を比較すると、イギリスのものは、truss 全体の形状に 合わせ対称的に架構されているのに対して、日本のものは、一箇所 ずつで補足的に用いられる構法である。

(2017 年 5 月 2 日原稿受理, 2017 年 7 月 7 日採用決定 